\title{
Universiteit
}

Leiden

The Netherlands

\section{Reading Augustine Through Erasmus' Eyes: Humanist Scholarship and Paratextual Guidance in the Wake of the Reformation} Visser, A.S.Q.

\section{Citation}

Visser, A. S. Q. (2008). Reading Augustine Through

Erasmus' Eyes: Humanist Scholarship and Paratextual Guidance in the Wake of the Reformation. Erasmus of Rotterdam Society Yearbook, 28, 67-90. Retrieved from https://hdl.handle.net/1887/14315

Version:

Not Applicable (or Unknown)

License:

Leiden University Non-exclusive license

Downloaded from: $\quad$ https://hdl.handle.net/1887/14315

Note: To cite this publication please use the final published version (if applicable). 


\title{
Reading Augustine through Erasmus' Eyes: Humanist Scholarship and Paratextual Guidance in the Wake of the Reformation*
}

\author{
Arnoud Visser
}

\begin{abstract}
This article investigates Erasmus' edition of the collected works of Augustine of Hippo (Basel I528-I529) as an example of the interaction between the scholarly culture of Renaissance humanism and the Reformation. It examines how Erasmus' reservations about Augustine's thought informed his presentation of the church father as a brilliant bishop but a mediocre writer. It shows how Erasmus' humanist perspective and theological agenda guided-and at times misguided - his editorial practice, such as in the assessment of authenticity. The result was an edition in which Augustine's works were framed by a highly ideological textual apparatus, which proved especially controversial in post-Tridentine Catholic circles.
\end{abstract}

Of all the church fathers Erasmus edited, Augustine presented him with the greatest challenge. It was literally enormous because Augustine and the numerous pseudo-Augustines had produced an oeuvre which was bigger than that of any other patristic author. Yet Erasmus' task was daunting in qualitative terms as well. The project was not just technically complicated; it was also politically sensitive, since it coincided with the theological debates of the I520s, in which Augustine occupied a central, though fiercely contested, place. Luther and Melanchthon had appropriated him, and in particular his antiPelagian works, for their own views on salvation, while conservative Catholics could appeal to Augustine's anti-Donatist works to fight the schism-makers. How, then, did Erasmus read Augustine? What impact, moreover, did Erasmus'

\footnotetext{
*) This article is part of a larger, collaborative project "After Augustine: A Survey of his Reception from 430 to 2000" (University of St Andrews), funded by the Leverhulme Trust. The Institut d'Histoire de la Réformation in Geneva generously enabled me to carry out much of the research. I wish to thank the anonymous reviewers of ERSY for their helpful suggestions, as well as Irena Backus, Hilmar Pabel, and seminar audiences at Emory University and the Oxford Patristics Conference for stimulating comments and questions.
} 
perspective have on the edition of Augustine's collected works brough out by the Froben publishing house in I528-I529?

These questions are interesting enough in themselves, but all the more important in view of the dissemination of Erasmus' Augustine. The edition was the successor to Johannes Amerbach's famous opera omnia edition (Basel, I505-1506), used by the first generation of Reformers. It was Erasmus' edition, however, that became the standard version of Augustine's works in the decades in which the Reformation took shape. No fewer than ten reprints were produced by publishers in Basel, Paris, and Venice. ${ }^{1}$ The text subsequently provided a starting-point for Augustinian collections, including anthologies, commonplace books and gospel harmonizations. ${ }^{2}$ Only in 1576-I577 was a new, emphatically Catholic edition published, edited by a team of theologians from the University of Leuven. Yet even this work did not end the impact of Erasmus' scholarship, insofar as it silently incorporated substantial parts of his annotations. $^{3}$

Erasmus' edition of Augustine thus crucially shaped the church father's reception in the wake of the Reformation. Yet surprisingly, this aspect of the work has so far received little attention. Augustine scholarship has studied the edition as part of the transmission of his works, evaluating the comparative technical merits and deficiencies of Erasmus' version. ${ }^{4}$ Experts on Erasmus, meanwhile, have mostly considered the edition to explore the forms and functions of the humanist's patristic activities in general. They have suggested various practical and theological motives behind his editorial

1) These reprints introduced some corrections and improvements but did not radically alter the presentation of the texts. See Pierre Petitmengin, "Editions princeps et Opera omnia de saint Augustin," in Augustinus in der Neuzeit, eds. K. Flasch and D. de Courcelles (Turnhout: Brepols, 1998), 33-5I, including a list of editions on 43.

2) Ludwig Rabus, Conciliationes locorum s. scripturae in specie pugnantium. Ex libris D. Aurelii Augustini Episcopi Hipponensis, per D. Ludovicum Rabus, fideli diligentia, nec non diligenti fidelitate conscriptae et editae. Cum locorum et rerum Indice triplici (Nuremberg: J. Montanus and U. Neuberus, I56I), sig. $\beta 3^{\mathrm{r}}$. The epitome edition of Joannes Piscator (Augsburg, I539), however, was based on the Amerbach edition, irregularly collated against the text of Erasmus' edition; see Olivier Fatio, "Un florilège augustinien du XVIe siècle: l'Omnium operum Divi Augustini Epitome de Johannes Piscatorius (I537)," Revue des études augustiniennes I8 (1972): 194-202.

3) See my "How Catholic was Augustine? Confessional Patristics and the Survival of Erasmus in the Counter-Reformation" (forthcoming in Journal of Ecclesiastical History).

4) Joseph De Ghellinck, Patristique et Moyen Age: étude d'histoire littéraire et doctrinale (Gembloux: J. Duculot, 1948), 3:378-392; Petitmengin, "Editions princeps et Opera omnia de saint Augustin." 
program, but it was not their aim to investigate Augustine in particular. ${ }^{5}$ Still more unexpectedly, Charles Béné, who devoted a monograph to Augustine's influence on Erasmus, does not pay attention to the opera omnia edition at all. ${ }^{6}$

This article aims to assess Erasmus' edition of Augustine in the light of the interaction between the scholarly culture of Renaissance humanism and the religious climate of the Reformation. It attempts to define Erasmus' editorial perspective more precisely and to gauge the implications of this perspective for his textual criticism, and, by extension, for his readers. The main body of evidence for this investigation is the paratextual material surrounding Erasmus' edition, which can be divided into two groups. ${ }^{7}$ The first is formed by the peritexts, those physically accompanying the main texts, such as the preliminary pages (e.g. title pages, dedicatory letters) and the critical apparatus (here consisting mainly of marginal notes and approximately eighty censurae, brief evaluations of individual works). The second group concerns the epitexts, including any material physically separate from the edition itself that provides relevant information about the work. These comprise, for instance, Erasmus' frequent comments about Augustine in his correspondence. Before we can examine Erasmus' presentation of Augustine, however, his edition must briefly be located in the context of his patristic agenda.

5) Robert Peters, "Erasmus and the Church Fathers: Their Practical Value," Church History 36 (1967): 254-26r; Pierre Petitmengin, "Comment étudier l'activité d'Érasme éditeur de textes antiques?" in Colloquia erasmiana turonensia, ed. J.C. Margolin (Toronto: University of Toronto Press, 1972), I:217-222; John C. Olin, "Erasmus and the Church Fathers" in Six Essays on Erasmus, ed. Olin (New York: Fordham University Press, 1979), 33-47; Jacques Chomarat, Grammaire et rhétorique chez Erasme (Paris: Société d'Edition des Belles Lettres, 198I), I:45I-507; John F. D'Amico, Theory and Practice in Renaissance Textual Criticism: Beatus Rhenanus Between Conjecture and History (Berkeley: University of California Press, 1988), 30-38; Irena Backus, "Erasmus and the Spirituality of the Early Church," in Erasmus' Vision of the Church, ed. Hilmar M. Pabel (Kirksville: Sixteenth Century Journal Publishers, I995), 95-II4; Jan den Boeft, "Erasmus and the Church Fathers," in The Reception of the Church Fathers in the West, ed. Irena Backus (Leiden: Brill, 1997), 2:537-572, and (from a broader perspective) Ueli Dill, "Die Arbeitsweise des Erasmus, beleuchtet anhand von fünf Basler Fragmenten," Dutch Review of Church History 79 (1999): I-38.

6) Charles Béné, Érasme et Saint Augustin, ou influence de Saint Augustin sur l'humanisme d'Érasme (Geneva: Droz, 1969).

7) Gérard Genette, Paratexts: Thresholds of Interpretation, trans. Jane E. Lewin (Cambridge: Cambridge University Press, 1997), I-I5. 


\section{Erasmus' Patristic Agenda}

The first reference to Erasmus' work on Augustine dates back to 1517, a year after the publication of his famous edition of Jerome. For the next ten years, Erasmus expended considerable energy on the project. ${ }^{8}$ Yet he was by no means the only editor involved. The Spanish humanist Juan Luis Vives, for example, took care of the City of God, which was first published separately in I522, together with a massive commentary. ${ }^{9}$ Martin Lipsius, member of the convent of St Martins at Leuven, was an important force behind the scenes, collating old manuscripts, making transcriptions and annotations, and assisting with proof-reading. ${ }^{10}$ Considering this collective effort, Erasmus seems remarkably

8) The project is first mentioned by Beatus Rhenanus to Erasmus, Ep. 58I, Io May I517. For an overview of the genesis, see Allen's introductions to Epp. 2157 (Erasmus' preface to the opera omnia) and 1309 (Erasmus' preface to Vives' De civitate dei). See, in addition, De Ghellinck, Patristique et Moyen Age, 378-392. Erasmus' precise contribution is difficult to assess. Apart from references in his correspondence, interesting samples of his editorial work can be found in twelve leaves of manuscript annotations on Augustine, preserved in the Royal Library in Copenhagen (Gammel Kongelig Samling [hereafter GKS] 95, fols $153^{\mathrm{r}}-159^{\mathrm{v}}$ ). The notes are mentioned by Allen (3:630-634) and C. Reedijk, "Three Erasmus Autographs in the Royal Library at Copenhagen," in Studia bibliographica in honorem Herman de la Fontaine Verwey: A Collection of Essays and Studies in Bibliography and Allied Subjects, ed. S. van der Woude (Amsterdam: Hertzberger \& Co., 1967), 327-349, esp. 333. Neither of them identified the precise nature of these autographs. They turn out to contain over eighty annotations to three works: the anti-Manichean treatise Contra Faustum and the antiDonatist works Contra Cresconium and Contra litteras Petiliani. More research is needed to assess the precise function of the notes. I am very grateful to Hans Trapman for alerting me to these notes and to Erik Petersen for his help at the Royal Library.

9) Miguel Batllori, "Juan Luis Vives, comentarista del De civitate Dei de San Agustín: Apuntes para una lección en torno a la ortodoxia de Vives," in Luis Vives y el humanismo Europeo, ed. Francisco Javier Fernández Nieto, et al. (Valencia: Universidad de Valencia, 1998), I47-159.

10) For Lipsius' research see the manuscript reading notes to various works of Augustine (De agone Christiano, De doctrina christiana, De natura boni, De ordine, Contra epistolam Manichaei, and some spurious works) preserved in the Royal Library in Brussels, described by Willem Lourdaux and Marcel Haverals, Bibliotheca Vallis Sancti Martini in Lovanio: Bijdrage tot de studie van het geestesleven in de Nederlanden (I5de-I8de eeuw), vol. I (Leuven: Universitaire Pers Leuven, 1978), nos. 35 (pp. 155-158), 47 (pp. 207-209), and 55 (pp. 232235). Further research could establish to what extent these notes were used for Erasmus' editorial project. Apart from Lipsius, others who assisted with the edition were Conradus Goclenius (Epp. 1778, I890, I899) and possibly Sigismundus Gelenius. For references to assistance and group work, see Epp. I, lines 37-38; 2I26, lines 227-230, and 2566, lines I28-I3I Allen. 
modest about the edition in a letter to the French chaplain Nicolaus Vesuvius from I528:

There will be no trace of me in this work, except that I removed mistakes as much as possible, marked the spurious texts, and classified the works according to thematic similarities. The preface will contain nothing that can offend anyone. ${ }^{11}$

From a philological perspective, these words suggest a rather alarming belief in the idea of editorial invisibility: removing mistakes, identifying spurious works, and introducing a classification are presented as neutral acts which would not affect the text itself. How could Erasmus support such an idea? He was not normally inclined to underestimate the impact of editorial decisions nor used to hiding his light under a bushel. Designed by Erasmus himself, the title page of the Augustine edition, for example, claims that "Desiderius Erasmus of Rotterdam" has purged the works "with superior care" of "countless mistakes" so that "the great church father can quite rightly be considered to be born again." 12 In other letters Erasmus certainly did not think this particular job had been either simple or unimportant. Over the years he had frequently complained about the "monstrous errors" he had found, about his "immense efforts," and about how "Augustine [was] killing" him. ${ }^{13}$

In fact, two practical considerations seem to have triggered Erasmus' modesty. The first concerns commercial interests. Erasmus remark follows a request for a printing privilege, which would formally protect the Froben firm against pirate-editions in the French kingdom. In this particular case, the editions represented a considerable financial investment. Since Johannes Froben had just died (1527), the success of the work was important for the continuity of the business. Erasmus' modesty was meant to avoid any problems

11) Ep. 2053, Erasmus to Nicolaus Vesuvius (2I September I528), lines 20-23 Allen: "In hoc opere nihil erit meum, nisi quod mendas quantum licuit submovi, notha subindicavi, et libros secundum materiarum congruentias digessi. Praefatio nihil habebit quod quenquam offendat." Unless otherwise indicated, all translations are the author's own.

12) "Primus tomus, omnium operum divi Aurelii Augustini Hipponensis episcopi, summa vigilantia repurgatorum a mendis innumeris, per Des. Erasmum Roterodamum, ut optimo iure tantus ecclesiae doctor renatus videri possit. Inspice lector, et fateberis hanc non vanam esse pollicitationem, quod si gratus etiam esse voles, non patieris tantum laboris, tantumque impensarum frustra sumptum esse." Erasmus' draft of the title page is preserved in the Universitätsbibliothek at Basel, Ms. Frey-Gryn. II. 9. I33, fol. IO".

13) Quoted respectively from Epp. 2033, lines 44-45; 204I, lines IO-I3; 2046, lines 409-43I Allen; see also Epp. I885, lines I85-I87; I910, lines 6-9; I92I, lines I3-I4; 2033, lines 44-45; 2038, lines I-2 Allen. 
in acquiring royal patronage. The fact that modesty seemed the most effective strategy for commercial success points to a political consideration, namely Erasmus' reputation as a religious maverick. He knew that authorities were not prepared to sanction the dissemination of controversial works. He was keen, therefore, to assure his contact person that this edition would contain Augustine only. By emphasizing the neutrality of the edition, Erasmus anticipated the suspicion of the authorities. Why would he have to do this?

The edition of Augustine was part of a larger editorial program, starting in I5I6 with the opera omnia of Jerome and ending with that of Origen, published posthumously in 1536. For Erasmus this program was not just a scholarly exercise but an instrument of theological reform. In his view, the fathers were both literary and ethical models, whose works presented the ideal antidote to the scholastic sophistry of the modern theologians. ${ }^{14}$ And yet these works needed to be rescued, since they had been shamefully neglected in the more recent past, something which angered Erasmus. In the preface to his edition of Jerome he sharply contrasts this development to the universal respect for relics:

The slippers of the saints and their drivel-stained napkins we put to our lips, and the books they wrote, the most sacred and most powerful relics of those holy men, we leave to lie neglected. A scrap of a saint's tunic or shirt we place in a gilded and bejewelled reliquary, and the books into which they put so much work, and in which we have the best part of them still living and breathing, we abandon to be gnawed at will by bug, worm, and cockroach. ${ }^{15}$

Erasmus clearly felt that these writings needed to be restored to their rightful places - a restoration that occupied him for over twenty years. Chronologically, Augustine takes ninth place. In the period between the first reference to the project and its final publication the bishop of Hippo had to give way to Cyprian, Arnobius, Hilary, Chrysostom, Irenaeus, Ambrose, and Athanasius. Together, these editions of the church fathers were to revive the spirituality of

14) Regarding Erasmus' attitude to the church fathers, see den Boeft, "Erasmus and the Church Fathers."

15) Ep. 396, Erasmus to Warham (i April I516), CWE 61: 5-6; lines 62-69 Allen: "Equidem ut non aspernor simplicem vulgi pietatem, ita non possum non mirari tam praeposterum multitudinis iudicium. Calceos sanctorum et sudariola mucco sordentia exosculamur, et eorundem libros, sanctissimas et efficacissimas divorum reliquias, neglectos iacere patimur. Tuniculam aut indusiolum divi aureis gemmatisque thecis reponimus, et libros ab illis elaboratos, in quibus id quod illorum fuit optimum nobis adhuc vivit spiratque, cymicibus, tineis ac blattis impune rodendos relinquimus." 
Christian antiquity. In this way, philological scholarship was instrumental in Erasmus' potentially contentious agenda for religious reform.

\section{Erasmus' Reservations about Augustine}

It is not surprising that Erasmus anticipated suspicion from the authorities; for he had long gained a reputation of being hostile to Augustine. This reputation was not without some foundation. Christiane Mellinghoff-Bourgerie has shown that Augustine was generally not a source of positive inspiration for Erasmus, as Béné had claimed, but an author he read with profound reservations. ${ }^{16}$ In her classification of Augustinian testimonia she points out that Erasmus' use and evaluation of Augustine were partly dictated by the argumentative setting. Thus, in an apologetic context he regularly used Augustine as a stock auctoritas to silence opponents. Conversely, in exegetical works, where the position of the church fathers required more extensive treatment, Erasmus could be critical of Augustine's thought. ${ }^{17}$ In the first edition of his Annotations on the New Testament (I516), for example, Erasmus made little use of Augustine's works, and when he did he was at times plainly dismissive. One unflattering characterization in particular caused offence:

Augustine was undeniably a saint and a man of integrity endowed with a keen mind, but immensely credulous, and, moreover, lacking the equipment of languages.... In his knowledge of the biblical languages he was so inferior to Jerome that it would be impudent to compare one man with the other. ${ }^{18}$

Even though the comparison of patristic authorities had a respectable humanist history, reaching back to Petrarch and his preference for Augustine, in the new context of the emerging Reformation Erasmus' preference for Jerome over Augustine was in and of itself a highly sensitive theological statement. ${ }^{19}$

16) Viviane Mellinghoff-Bourgerie, "Erasme éditeur et interprète de Saint Augustin,” in Augustinus in der Neuzeit, 53-81. In her discussion of Bénés thesis Mellinghoff builds on similar criticisms by Chomarat, Grammaire et rhétorique, I:I67-179.

17) Mellinghoff-Bourgerie, "Erasme éditeur et interprète de Saint Augustin," 56-62.

18) Quoted by Erika Rummel, Erasmus' Annotations on the New Testament. From Philologist

to Theologian (Toronto: Toronto University Press, 1986), 59. The comment is made in Annotationes in Iohannem 21:22, ASD VI-6: I70-17I, lines 169-192. In the edition of I5I9 the criticism was muted.

19) Eugene Rice, Saint Jerome in the Renaissance (Baltimore: Johns Hopkins University Press, 1985), 137; for Petrarch's appropriation of Augustine, see Carol Quillen, Rereading the Renaissance: Petrarch, Augustine, and the Language of Humanism (Ann Arbor: University 
Both Protestants and Catholics disagreed with Erasmus' preferences. Martin Luther, for example, thought exactly the opposite. "I know no writer whom I hate as much as I do Jerome," he observed in one of his dinner conversations, because "all he writes about is fasting and virginity." 20 The (former) Augustinian hermit Luther is keen to alert the (former) Augustinian canon Erasmus to the specific importance of Augustine. Significantly, Luther's first attempt to establish contact with Erasmus, through Georg Spalatin in 1516, already contains the advice to study his favorite church father more closely, especially the anti-Pelagian works. This would not just improve Erasmus' understanding of Paul's letter to the Romans but also increase his regard for Augustine. ${ }^{21}$

Conservative Catholics also urged Erasmus to devote more attention to Augustine. The young theologians Edward Lee and Johann Eck, as well as the powerful syndic of the theological faculty of Paris, Noel Beda, all pressed him at various times to read specific works, assuming, on the basis of Erasmus' criticisms of Augustine, that he had not done so. ${ }^{22}$ Eck suggested furthermore that he was not the only one concerned about Erasmus' scanty knowledge of Augustine:
[A]nd there is no shortcoming in you which your supporters [i.e. the Erasmici] so much regret as your failure to have read Augustine. Cease therefore, dear Erasmus, to darken by your criticisms a leading light of the church, than which none has been more illustrious since its first pillars. Admit rather that Augustine was a great scholar, steep yourself in his works and turn his pages with all diligence, and you will regard as quite shameless the man who dares prefer any of the Fathers to Augustine as a scholar. ${ }^{23}$

of Michigan Press, 1998); for the contrast between Augustine and Jerome, see Quillen, Rereading the Renaissance, IOO-IOI, I27-I29.

20) Rice, Saint Jerome in the Renaissance, $137-\mathrm{I} 44$, with quotation from Luther's Tischreden at 139. For Erasmus' neglect of Augustine, see Luther, Werke. Kritische Gesamtausgabe (Weimar: Verlag Hermann Böhlaus Nachfolger, 1930), vol. I: Briefwechsel, nos. 27, lines 17-24, and 35, lines $15-26$.

21) Ep. 50I, Spalatin to Erasmus (II December 15I6), lines 49-6o Allen.

22) For Lee and Eck, see Erika Rummel, Erasmus and his Catholic Critics. I: I5I5-I522 (Nieuwkoop: De Graaff, I989), 47-48, I03; for Beda, see Ep. I579 (I525), lines 76-80 Allen, and Erasmus' response in Epp. 158I and 1596.

23) Ep. 769 (2 February I5I8), lines I07-II4 CWE; lines 92-99 Allen: "Nihil autem est quod tibi deesse Erasmici omnes adeo conquerantur, nisi quod A. Augustinum non legeris. Noli ergo, Erasme, tantum Ecclesiae lumen, quo post primas Ecclesiae columnas nullum fuit illustrius, tuo iudicio obtenebrare. Agnosce potius doctissimum fuisse Augustinum, eius amplectere scripta, versare in illis non indiligenter; impudentissimum profecto eum iudicabis qui aliquem ex doctoribus eruditione Augustino audeat praeferre." 
Eck's remark about Erasmus' bad reputation in matters Augustinian is a double-edged sword. It not only accuses Erasmus of a lack of knowledge but also turns him into the leader of an intellectual movement, the Erasmici. Such an association was dangerous. During the I5IOs, traditional theologians and humanists were engaged in fierce polemics (e.g. the Reuchlin affair), in which the former readily associated the program of the "Erasmians" with an heretical agenda for religious reform. In this context, Eck's comment could easily conjure up associations with the evangelicals and their preference for the anti-Pelagian Augustine. ${ }^{24}$

In his response to Eck, published soon afterwards, Erasmus promptly deals with the issue of followers by claiming that he cannot imagine why anyone would wish to be considered "Erasmian": "I absolutely loath these names of factions. We are all Christ's, and it is for his glory alone that we labour each according to his share." ${ }^{25}$ Regarding Augustine he actually sharpens his judgment but simultaneously tries to prove his respect by referring to his scholarly commitment: "I learn more of Christian philosophy from a single page of Origen than from ten of Augustine.... All the same, my love of Augustine is great enough for me to have attempted in an edition of his works to do for him what I did for Jerome." 26 Yet Eck was right about Erasmus' reputation. Not only among enemies but even among friends the humanist appears to have been considered a critic of Augustine. The correspondence with Martin Lipsius, for example, which, in contrast to the exchange with Eck, was never intended to be published, frequently discusses the issue. Lipsius too urged Erasmus to produce an edition of Augustine. It would bring him many new friends, Lipsius thought, "for Jerome's style is not to everyone's taste." ${ }^{27}$

24) For the perception of a close link between humanists and the early Reformers, see Erika Rummel, The Confessionalization of Humanism in Reformation Germany (Oxford: Oxford University Press, 2000), 9-29.

25) Ep. 844, lines 188-190 CWE; lines 169-172 Allen: "Nihil equidem in me agnosco, vir egregie, cur quisquam velit esse Erasmicus, et prorsus odi ista dissidiorum nomina, Christi sumus omnes, et in illius unius gloriam pro sua quisque portione sudamus." For Erasmus' desire to be his own man, see Chomarat, Grammaire et rhétorique, 2:I132-II34.

26) Ep. 844, lines 274-276 CWE; lines 25I-256 Allen: "Quid aliis usui veniat nescio; in me certe comperio quod dicam, 'Plus me docet Christianae philosophiae unica Origenis pagina quam decem Augustini.'... Et tamen Augustinus sic amo ut in aedendis huius voluminibus tentarim quod in Hieronymo praestimus." See also Ep. 898, Erasmus to Martin Lipsius (c. October 1518).

27) Ep. 922 (March I519), line 40 Allen; CWE 6: 259, lines 44-45. 
It is clear, therefore, that Erasmus' commitment to the edition of Augustine was surrounded by controversy. The fact that both Luther and conservative scholastic theologians had frequently claimed Augustine as their guiding light made the conditions for a philological restoration especially challenging, and these particular challenges certainly did not make Erasmus enthusiastic about Augustine's theology. The prominent role given to him by Luther in the debate on free will, for example, leads Erasmus to a particularly damning characterization of Augustine in the Hyperaspistes:

Luther is quite right to favor Augustine, who is such a pious and famous Doctor of the church, though... he is hardly consistent:... he detests scholastic theology, while this was generated by Augustine exactly as Minerva was from the brain of Jupiter.... ${ }^{28}$

How, then, did the polarized religious context and Erasmus' personal reservations about Augustine's thought inform his edition?

\section{Erasmus' Portrayal of Augustine}

In his portrayal of Augustine, Erasmus depicts a brilliant bishop but a mediocre writer. This point is first made in 1529 in his dedicatory letter to Archbishop Alfonso Fonseca of Toledo (Ep. 2157). ${ }^{29}$ While enumerating the assets of each of the church fathers, Erasmus specifies that Augustine exceeds all of them as a bishop. It is as if the Holy Spirit wished to present an episcopal model, in which all the requirements are united. ${ }^{30}$ Erasmus' preference for Augustine's pastoral qualities over his intellectual production is particularly outspoken in his preface to volume two, containing the letters. More than any other work, Erasmus writes, the correspondence reveals Augustine's principal virtues: "piety, charity, clemency, kindness, politeness, care of the flock entrusted to him, love of unity and a passion for God's house." Again, Erasmus emphasizes Augustine's merits as a bishop, comparing him to an "evangelical hen, careful and concerned to protect and cherish her chicks under her wings." ${ }^{1}$

28) Hyperaspistes II, LB X: I495D: "scholasticam theologicam, quam Augustinus non aliter quam Iupiter Minervam e cerebro suo genuit.” See also Chomarat, Grammaire et rhétorique, I:I77.

29) For a comparative assessment of Erasmus' patristic prefaces see Backus, "Erasmus and the Spirituality of the Early Church."

30) Ep. 2157, lines Io-29 Allen.

31) Letter to the reader, vol. 2, sig. [av ]: "Illud ausim affirmare, non alio in opere magis elucescere sanctissimi viri, pietatem, charitatem, mansuetudinem, humanitatem, civilitatem, 
These pastoral qualities are meant to absolve Augustine of his literary imperfections. Indeed, Erasmus has little positive to say about the church father's style:

For Augustine has his own particular literary style, talkative, wrapping up much information in tortuous sentences, which requires a reader who is experienced, shrewd, careful, endowed with a good memory and willing to do tedious, hard work. And there are not many such readers. ${ }^{32}$

Similar remarks frequently appear in the censurae to individual works or in the marginal annotations. Verbosity is one of the major irritations. In his censura to De trinitate Erasmus criticizes Augustine's combination of obscurity and "garrulousness," which is "virtually never-ending." ${ }^{33}$ In other works Erasmus occasionally signals disagreement with Augustine's arguments by adding qualifications in Greek to the margins, such as "harsh" (sklèron) or "cold" (psychron). ${ }^{34}$

Erasmus also has serious problems with the Confessions. Written by and for "someone with time on his hands," the "specific annoyances" of this work are, first, the fact that Augustine talks too much about himself, which seems to betray a certain level of inverted modesty, and second, the "rather silly, not to say sordid" topics about which he speaks, "such as childhood, adolescence, his feelings of lust and similar things." Moreover, in his attempt to elevate the subject with a grander style, the text sometimes becomes "rather obscure." 35 The main profit of reading the Confessions, according to Erasmus, is

studium crediti gregis, amorem concordantiae, et zelum domus dei." He continues: "Videas vere gallinam evangelicam sollicitam et anxiam, ut sub alas colligat foveatque pullos suos." For the image of the hen, cf. Matthew 23:37.

32) Ep. 2157, lines 379-383 Allen: "Habet enim Augustinus suum quoddam dicendi genus, argutum et periodis in longum productis multa convolens, quod lectorem et familiarem et acutum et attentum et bene memorem requirit, denique tedii laborisque patientem, quales non ita multos reperias."

33) Vol. 3, p. 340: "Iam multiloquium huic pene perpetuum est, quod accidit illi docendi studio, dum cupit quae scribit etiam a parum eruditis ac tardis intelligi. Obscuritas hinc accidit, in hoc duntaxat opere, quod quum res per se sit obscurissima, eoque dilucidis imaginibus adhibitis illustranda, ille trinitatis imagines petit ab his rebus, quae nec vulgo satis notae sunt, nec inter eruditos admodum confessae, postremo tales, ut ipsae potius egeant illustratione, quam ut obscurissimis lucem possint invehere."

34) For sklèron, see, for instance, Ep. 19, vol. 2, p. 45; Ep. 50, vol. 2, p. I4I; De consensu evangelistarum, bk 3, vol. 4, p. 342; for psychron, ibid., p. 34I and vol. I, p. 360 (Soliloquiorum libri ii, bk I, cap. 2).

35) Censura to the Retractationes et Confessiones, vol. I, p. 45: "Porro confessionum libri 
twofold: first, ethical, since it reveals Augustine's piety and charity; and second, hermeneutical, since it will help the reader to understand Augustine's other "letters and dialogues." For without knowledge of the historical context of his life and Augustine's predispositions, the reader may be troubled by "a certain display of chattiness, convoluted sentences, a style that sometimes sinks to common language, and a frequent repetition of these elements-one might say that at times a passage is a bit vain and the product of someone who is unduly pleased with himself." 36

To explain Augustine's shortcomings Erasmus repeatedly points at two historical, conveniently external factors, namely women and Africa:

This mind would have given us richer fruits, if he had had the luck to be born in Italy or Gaul, or to have lived there. Africa was primitive, hedonistic, anti-intellectual and addicted to scandal. Hence they [i.e. Augustine's African correspondents] frequently trouble him with problems that are a bit trivial and do not contribute much to piety. And he is often forced to adapt his pen to the feelings of his people/nation. Really one would need a substantial farmer to cultivate such a thicket. Yet he would have written texts more worthwhile to read, if he had conformed to the norms of the Romans or the Greeks, or if he had made less allowance for the inexperience of the uneducated. But for Christian charity it is more important to help as many as possible than to receive esteem from distinguished persons; charity is thirstier for the salvation of one's neighbor, than for its own glory. Some people, however, "the ladies" in particular, were obsessed with a certain pious determination, believing it a beautiful thing to obtain anything in writing from the bishop. Since the pious man grants everyone's wishes, this has therefore created the situation that he is sometimes less rewarding to the demanding reader. ${ }^{37}$

quos et ociosus et ociosis scripsisse videtur, habent quiddam peculiaris molestiae. Primum in hoc quod multa de seipso commemorat, partim minutiora, quam ut ea severiore praeditus ingenio commemoranda putaret, partim ad gloriae speciem accedentia. Quid autem fastidiosius, quam humani livor ingenii, si quis quid quamlibet modeste de seipso praedicet? Ad haec, dum rebus humilioribus ne dicam sordidioribus, velut de infantia, de ephebia, de affectu libidinis, deque similibus verba faciens, studet iis quae dicuntur orationis honorem addere, veluti pudorem sententiarum, hoc velo tegens, fit hac occasione nonnunquam obscurior. Verum haec tediola si devoraris, reliqua cum maiore tum fructu tum voluptate perleges." For the inverted modesty of the Confessions, see also Erasmus' letter to Pieter Wichmans, (c. 29 August I52I), Ep. I23I, lines 23-24 Allen.

36) Censura to the Retractationes et Confessiones, vol. I, p. 45: "Nec dubito quin hoc multis usu veniat eorum, qui recens ad Augustinianorum voluminum lectionem velut in colloquium veniunt. Offendit species quaedam loquacitatis, offendunt in longum productae periodi, offendit oratio nonnunquam ad popularem sermonem degenerans, offendit earundem rerum crebra repetitio, dicas alicubi quiddam esse subinane, et affectum hominis sibi plus aequo placentis."

37) Erasmus' letter to the reader in vol. 2, sig. [av $\left.{ }^{\mathrm{v}}\right]$ : "Uberiores fructus nobis dedisset illud 
Erasmus' point is cleverly made: his criticism of Augustine is transformed into an argument for his pastoral skills. By foregrounding the moral dimension, Erasmus can also pursue his own agenda for ethical reform among the clergy. For example, even Augustine's wild life-style before his conversion is used to hold up a mirror: true, Augustine had concubines, but at least he remained loyal to them, whereas "you will not easily find this moral integrity in priests and abbots today." ${ }^{38}$ In this way, the representation of Augustine explicitly responds to the religious developments of Erasmus' time.

In light of Erasmus' outspoken stylistic criticism and his historical explanations, it is easy to see why Mellinghoff-Bourgerie believed that his avowed grammatical approach promoted a "desacralized reading." According to her, grammatical analysis enabled Erasmus to emancipate himself from Augustine and deconstruct traditional dogmatic theology in favor of a strictly biblical perspective. ${ }^{39}$ Yet is it accurate to characterize Erasmus' approach as purely grammatical in the first place? We have seen that his own claims in this direction serve specific rhetorical purposes. When compared to his portrayal of Augustine, moreover, these claims seem unconvincing. For Erasmus routinely gives his "grammatical" reservations an ethical perspective. Augustine is still represented as an exemplary saint, whose talents as a bishop deserve to be imitated in the contemporary church. In this sense, Erasmus' reading combines intellectual criticism with ethical devotion. Rather than considering his grammatical attention as a-theological, then, it seems more appropriate to understand it as anti-scholastic. The effect is not so much to desacralize Augustine as to redefine his holiness.

ingenium, si in Italia, Galliave vel nasci vel vivere contigisset. Rudis erat Africa, voluptatum avida, studiorum inimica, curiosarum rerum appetens. Unde frequenter exercent illum quaestionibus subfrivolis, nec multum facientibus ad pietatem: et ad suae gentis affectus saepe cogitur attemperare calamum. Verum tali excolendo senticeto, tali opus erat agricola. Quanquam digniora lectu scripturus erat, si vel ad Romanorum aut Graecorum iudicia se composuisset, vel minus indulsisset simplicium imperitiae. Sed Christiana charitas prius habet prodesse quam plurimis, quam probari praecipuis, fraternae salutis quam suae gloriae sitientior. Quosdam autem, praecipue mulierculas pia quaedam habebat ambitio, pulchrum esse ducentes, qualecunque scriptum impetrasse $a b$ episcopo. Ita factum est, ut dum vir pius omnium votis obsequitur, minus alicubi satis faciat lectori fastidioso." For the characteristics of an "African style" see also Erasmus' preface to his edition of Hilary (I523), Ep. I334, lines 304-318 Allen.

38) Ep. 2157, lines 35-38 Allen: "Adolescens habuit concubinam, quod humanae permittunt leges; et hac non repudiata sed erepta, ascivit alteram. Verum utrique servavit coniugii fidem: quam probitatem hodie non temere reperias in sacerdotibus aut abbatibus."

39) Mellinghoff-Bourgerie, "Erasme éditeur et interprète de Saint Augustin," 74. 
That Erasmus' approach is not straightforwardly grammatical also becomes clear from the strategic silences in the edition. Where his edition of Jerome provided extensive scholia, with summarizing argumentum, argumentative antidotus and sometimes line by line commentary, the works of Augustine are only supported by preliminaries, marginal notes, and occasional censurae. There are indications, moreover, that the limited supply of commentary is a consequence of the escalation of the Reformation debates. In the early I520s, for example, Erasmus still speaks of an edition which will contain scholia, but by 1528 he writes that these will not be included, except in particular places to explain textual corruption. ${ }^{40}$ In the meantime, in the 1522 preface to the edition of City of God, Erasmus makes a connection between attacks on his supposed ignorance of Augustine, in this case from the Dominicans, and his editorial policy. In his complete edition, he writes, he does not intend to deal with theological subtleties but will focus purely on the grammatical issues (Ep. I309, lines 59-79 Allen). And again later Erasmus adduces a strictly grammatical perspective and the absence of scholia to prove the theological neutrality of the edition. "So there is nothing I did which they need fear," Erasmus writes in a letter to Nicholas Vesuvius, still trying to secure a printing privilege. ${ }^{41}$ The "they" in question, namely opponents of Erasmus' patristic research within the orders, could be satisfied: their pressure had not been without effect.

A final example of how external considerations neutralized Erasmus' scholarship and silenced his editorial voice concerns the organization of the edition. Erasmus initially planned to relegate all spurious works to the last volume. The Confessions would be printed together with the contemplative works. ${ }^{42}$ This plan was probably abandoned for commercial reasons. Already

40) Epp. II44 to Francesco Chieregato (I3 September I520) and I2O4 to Adrian Barland (May? I52I) refer to scholia, while Epp. 2046 to Germanus Brixius (6 September 1528) and 2075 to Nicholas Vesuvius (November 1528) specify that there will be no annotations.

41) Ep. 2075, (November I528), line II Allen. That annotations would probably have made Erasmus' theological reading more explicit is exemplified by the reading notes in the Copenhagen manuscript (note 8 above), where one can find evaluative summaries, indignant corrections, and some topical references. See, for instance, Erasmus' note to Against Faustus, 32.IO, where Augustine discusses ICorinthians 3:4 ("For while one saith, I am of Paul; and another, I am of Apollos; are you not carnal?") (GKS 95, fol. I59v): "Legant hoc caput qui gaudent subinde nova monasteria instituere, sed inditis novis vocabulis, aut dico novo cultu novoque vivendi ritu." ("Let this paragraph be read by those who enjoy setting up new monasteries continually, but with new names, or indeed with a new cult and new life-style.")

42) Ep.I, to John Botzheim (30 January 1523), containing a catalogue of his own works, lines I8-4I Allen. 
in I5I4, Erasmus suggests a similar restructuring of the works of Jerome, only to receive a negative response. Changing the traditional order as laid out by Amerbach would "inflict no small loss on the booksellers" and cause confusion to the readers. ${ }^{43}$

The representation of Augustine, then, is clearly colored by Erasmus' reservations and predilections. It reveals how his sensitivity to the religious climate informed his editorial perspective in various ways. At times it prompted outspoken criticism, but in other respects it brought, above all, silence. In the overall assessment Erasmus tries to keep a balance between his intellectual reservations and his appreciation for Augustine's pastoral virtues. These different characteristics make it particularly interesting to investigate how Erasmus' perspective affected his scholarly judgment. For this the problem of authenticity is an excellent testcase.

\section{Erasmus' Assessment of Spurious Works}

Pseudepigraphy was a major problem in the Augustinian corpus. Of all incunables published under Augustine's name, for instance, almost two thirds (II6 out of 187) were, in fact, spurious. ${ }^{44}$ Some of these texts had been used for centuries to legitimize established theological positions. As a result, crucial works, such as Thomas Aquinas' Summa theologiae or Gratian's Decretum, were full of references to Pseudo-Augustinian writings. Exposing these works was one of Erasmus' main aims. Those he considered inauthentic were preceded by censurae typically explaining his conclusion with historical and stylistic arguments. ${ }^{45}$ His awareness of the historical development of Latin enabled

43) Gregor Reisch to Erasmus, Ep. 309 (4 October I5I4), lines II-I6 CWE; lines 8-I2 Allen. 44) John Monfasani, "The De doctrina christiana and Renaissance Rhetoric," in Reading and Wisdom: The De Doctrina Christiana of Augustine in the Middle Ages, ed. Edward D. English (Notre Dame: University of Notre Dame Press, 1995), 172-188, at 174; see further M. de Kroon, "Pseudo-Augustin im Mittelalter: Entwurf eines Forschungberichts," Augustiniana 22 (I972): 5II-530.

45) Regarding Erasmus' skills in this area, see Robert Sider, "Erasmus and Ancient Christian Writers: The Search for Authenticity," in Nova et Vetera: Patristic Studies in Honor of Patrick Halton, ed. John Petruccione (Washington, D.C.: Catholic University of America Press, 1998). In the case of pagan authors, Erasmus considered the problem of pseudepigraphy in itself less urgent (so long as the work was deemed good). See Jill Kraye, "Erasmus and the Canonization of Aristotle: The Letter to John More," in England and the Continental Renaissance: Essays in Honour of J.B. Trapp, eds. Edward Chaney and Peter Mack (Woodbridge: Boydell, 1990), 37-52, esp. 44-49; rpt. in Kraye, Classical Traditions in Renaissance Philosophy (Aldershot: Ashgate, 2002), no. I2. 
him to make some solid judgments. For example, the use of unclassical words, like nullatenus or potentialiter, led Erasmus to conclude that certain works were written long after Augustine's death. ${ }^{46}$ In the case of De vera ac falsa poenitentia Erasmus points out that the text explicitly quotes Augustine and then disapproves of it, something Augustine was unlikely to have done himself, outside of his Retractationes.

Erasmus' aesthetic arguments reflect similar acumen but simultaneously show how personal tastes and opinions could lead the editor astray. For instance, he admits he would not have recognized the Speculum as authentic if Augustine's contemporary biographer, Possidius, had not confirmed the authorship. Rather than Augustine's guide to the teachings of the Bible, Erasmus prefers the "more intelligent and refined" treatment offered by Cyprian and "some of the Greeks." ${ }^{47}$ Elsewhere he was plainly wrong. A case in point is De bono viduitatis of which, according to Erasmus, "the remarkable ease and clarity of expression scream out that it is not by Augustine." Similarly, he denies Augustine's authorship of the treatises De patientia and De continentia. Here the style leads him to suspect the hand of Hugh of St Victor. ${ }^{48}$

Apart from the reasoning, there is the presentation. Both in his historical and aesthetic arguments, Erasmus adopts a highly personal tone. Speaking in his editorial voice, he uses the first person singular, addresses the reader, and displays a lively temperament. Impatience, irritation and indignation frequently accompany the discussion of spurious texts. He describes the style of De salutaribus documentis as "pious chatter," and borrowing from Horace, criticizes the organization of another work as "the idle dreams of a sick man." 49

46) See, for instance, Erasmus' censurae to Augustine's Opera omnia (Basel, 1528/29), De fide ad Petrum diaconum, vol. 3, p. 148 and Quaestionum lxv dialogus, vol. 4, p. 480.

47) Vol. 3, p. 644: "Hoc opus vix eram ascripturus Augustino, nisi Posidonius... in vita nominatim illi tribuisset, et praefatio non abhorret ab eius stilo. Versatus est in simili negocio Cyprianus, et apud Graecos nonnulli, sed maiore ingenio curaque. Caeterum infimis etiam inservire gaudet christiana charitas."

48) Censura to De bono viduitatis, vol. 4, p. 725: "Mira dictionis facilitas et candor clamitat non esse Augustini. Probabile est Iuliani. ...” For De continentia and De patientia see vol. 4, p. 703 and 717 respectively.

49) De salutaribus documentis, vol. 4, p. 750: "Qui scribit hunc libellum subindicat se fuisse clericum, qui secesserit ad vitae correctionem, Laicum autem fuisse cui scribit. Apparet hominem fuisse pium, sed absque litteris: nam sermo nec purus est, nec cohaeret alicubi, sed habet tamen piam loquacitatem. Quanquam haec Augustino tribuere summae sit impudentiae." The Horatian expression is taken from Ars poetica, 7. See also the censura on 
This tone can quickly take on a political edge. In one of Augustine's letters, for example, he finds "something ridiculous": a gloss containing a rather crude etymology of the word "apostle." Amazed, Erasmus claims he "never saw anything more stupid," and, addressing the reader, tries to score his humanistic point: "While such monstrous corruptions can be found in the books of the orthodox, there are nevertheless those who take offence at us, because we dare to correct some of these errors." 50

Erasmus' review of spurious works also contains positive judgments. Here, too, his appraisal clearly reveals his personal preferences. For example, he appreciates texts which are "learned" or "well written." ${ }^{51}$ He can understand that some books originate in laudable exercises to improve stylistic skills (as in De incarnatione verbi lib. $i$ and De trinitate et unitate dei). His association of Augustine with verbosity makes him see brevity as a sign of spurious authorship and, more generally, appreciate summaries of his works. The Quaestionum LXV dialogus he considers a useful "synopsis" of what Augustine discussed "in a technical and protracted way." 52 In these cases, Erasmus' only criticism is that spurious works place an unacceptable burden on the edition and that the authors use Augustine's fame to their own advantage. Such remarks are particularly interesting considering Erasmus' own track record in this area,

Vigintiunius sententiarum lib. I, vol. 4, p. 43I: "Constat hunc librum a studioso quopiam ex variis autoribus temere nulloque ordine congestum, velut aegri somnia vana...."

50) Censura on Ep. 58, vol. 2, p. I84: "In hac epistola comperi quiddam ridiculum. Paulinus in loco quo Paulus refert alios datos prophetas, alios apostolos, non putat eum sentire de prophetis veteris testamenti, sed de alio genere prophetarum. Hic quidam assuerat pannum, veluti pro Augustino respondens, quo nihil vidi stultius. Inerant enim haec verba, Ut enim ad vim termini proficiscar, apostolus graecum dicitur apos quod notat augmentum vel praeminentiam, et stolon quod est missio, quasi praeminenter missus ad augmentationem scilicet fidei catholicae. Habes gustum optime lector, unde reliqua coniectes, leonem ut aiunt, ab unguibus. Assumentum ridicule fuerat interiectum inter nomen appellativum et epitheton, temporis videlicet et sequuturi. Haec portenta quum deprehendantur in libris orthodoxorum, tamen quidam indignantur nobis, quod audemus quaedam restituere." This is apparently one of the most spectacular corruptions Erasmus came across, since he comes back to it in the general dedication letter to Alfonso Fonseca, Ep. 2157, lines 426-442 Allen.

51) On the former quality see Ep. 38, vol. 2, p. 88 and Ep. 45, vol. 2, p. IOo; on the latter, see De altercatione ecclesiae et synagogae dialogus, vol. 6, p. 54 .

52) Vol. 4, p. 480: "Non damno studium illius, qui quae in Augustini libris et subtiliter et prolixe disputata fuerant, contraxit in compendium: verum ad hunc modum in immensum crescunt volumina. Hoc ita lectorem monitum esse volui, ut si meum iudicium non probat, fruatur suo." 
since he himself has been unmasked as the author of a spurious treatise included in the fourth edition of Cyprian's works (I530). ${ }^{53}$

Far from being an invisible editor, as Erasmus claimed in his letter to Vesuvius, he is markedly present in the critical apparatus. It is hardly surprising, then, that his idiosyncratic review of the Augustinian canon offended the theological establishment. Erasmus' treatment of the monastic Rule may serve as a case in point. Since the eleventh century this text had been a practical guide for a multitude of religious communities and orders. Of the three texts included in this Rule, Erasmus declares two spurious in characteristically brusque terms. "I ask you, reader," he introduces the first one, "what sense of propriety, what intelligence do those who attribute such nonsense to such a great man have?" The second rule he deems "of the same sort." 54 The third is authentic, but probably written for women rather than men.

This was unwelcome news for the many clergymen who lived by this rule and in some cases believed their order was founded by Augustine himself, when he led a small religious community in Tagaste from 388 to 49r. Erasmus throws oil on the flames by claiming that Augustine had never called himself a monk. His ideas about religious community, Erasmus explains, differed fundamentally from the contemporary orders. Although he was not the first to make this suggestion-in I506 Jacob Wimfeling had landed in trouble for similar reasons - the combination of arguments made Erasmus' censura unacceptable for clerical authorities throughout Europe. ${ }^{55}$ The Paris Faculty of Theology, for example, officially condemned the censura in 1540 and somewhat later placed it on its index of forbidden books (I544). This was soon followed by bans in Portugal and Spain. ${ }^{56}$

53) S. Seidel Menchi, "Un'opera misconosciuta di Erasmo? Il trattato pseudo-ciprianico 'De duplici martyrio," Rivista storica italiana 90 (1978): 709-743.

54) Vol. I, p. 590: "Obsecro te lector, quid habent frontis ac mentis qui tales naenias asscribunt tali viro? ... Regula secunda eiusdem farinae, cuius superior."

55) See notes to Ep. 333, lines $132-135$ and Ep. 2088, line 93 Allen. For modern interpretations of Augustine's life at Tagaste, see George Lawless, Augustine of Hippo and his Monastic Rule (Oxford: Oxford University Press, 1987), 45-58.

56) See Index des livres interdits, I: Index de l'Université de Paris, eds. J.M. de Bujanda, Francis M. Higman and James K. Farge (Sherbrooke: Centre d'Etudes de la Renaissance, I985), I79-I80. 


\section{Confessionalization, Dissemination and Consumption}

As the confessional pressures increased in the course of the sixteenth century, Erasmus' edition became yet more controversial within the Catholic world. This growing controversy culminated in the ban on the entire edition in the first papal Index of Prohibited Books (I557). ${ }^{57}$ Yet since stopping the circulation of Augustine's collected works altogether was rather impractical, the ban was soon modified. Nevertheless, it took a long time before the censorship procedure was clarified. In 1562, at the final stage of the Council of Trent, a committee was set up to review the list of forbidden books (session I8, De librorum delectu). It reported that a comprehensive judgment was impossible, due to the sheer variety of book production, and referred the matter to the pope (session 25 , 4 December 1563), who then issued a practical set of rules, De libris prohibitis regulae decem (1564), which allowed for some tolerance of books which only contained suspect passages but were not entirely heretical. ${ }^{58}$

In the case of Erasmus' Augustine, excision of the controversial elements was seen as the best solution to stop the dissemination of heretical ideas. A detailed list of offensive elements can be found in the Index expurgatorius produced by the University of Leuven (I57I) as part of the implementation of the Council of Trent in the Low Countries. Here we find approximately seventy suggestions for deletions in the prefatory material, marginal notes, and censurae, as well as over twenty deletions for the indices. The majority of the items concern anti-clerical language. ${ }^{59}$ The previously mentioned comparison between Augustine's loyalty to his concubine and the morals of modern priests, for instance, was the first

57) For all listings on the indices of forbidden books, see Index des livres interdits, Io: Thesaurus de la littérature interdite au xvie siècle. Auteurs, ouvrages, éditions, ed. J.M. de Bujanda, et al. (Sherbrooke: Centre d'Etudes de la Renaissance, 1996), esp. I70. For the approach of the Roman censors to Erasmus, see Silvana Seidel Menchi, "Whether to Remove Erasmus from the Index of Prohibited Books: Debates in the Roman Curia, I570-1610," ERSY 20 (2000): 19-33.

58) See The canons and decrees of the sacred and ecumenical Council of Trent, trans. James Waterworth (London: C. Dolman, 1848). For a survey of the sessions at Trent, see Michael A. Mullett, The Catholic Reformation (London: Routledge, 1999), 29-68; for a comprehensive history, see Hubert Jedin, Geschichte des Konzils von Trient, 4 vols. (Freiburg: Herder, 1949-1975).

59) Reprinted in Index des livres interdits, 7: Index d'Anvers. I569, I570, I57I, ed. J.M. de Bujanda, et al. (Sherbrooke: Centre d'Etudes de la Renaissance, 1988), 727-730. For its genesis, see G. van Calster, "La censure Louvaniste du Nouveau Testament," in Scrinium Erasmianum, ed. J. Coppens (Leiden: Brill, 1969), 386-391. This index was followed by the Spanish inquisition in their Index librorum expurgatorum of 1584 . See Index des livres interdits, 
item on the list. Yet it also included a correction of Erasmus' judgment about De bono viduitatis, which he had wrongly considered spurious. Altogether, Catholic censorship is a clear example of the attempt to prevent individual users from reading Augustine through Erasmus' eyes. Explanations for this agenda can be found in the criticism by various Catholic theologians of Erasmus' patristic scholarship. In his introduction to the Confessio Augustiniana, a polemical anthology of Augustine's works, the Jesuit Hieronymus Torrensis, for example, characterizes the implications of an Erasmian reading in clear terms: Erasmus' assessment privileges style over substance and creates "overly captious" readers. ${ }^{60}$

For the Protestant world, there are no central indicators to the reception of Erasmus' Augustine. Some evidence suggests that the same confessional pressures actually contributed to the survival of his edition even decades after the publication of the new Augustine of the Leuven theologians. In the Low Countries, for example, we find only Erasmus' version in the libraries of the two universities, Leiden and Franeker, both of which had strongly Calvinist theological faculties. ${ }^{61}$ Similarly, the Dutch theologians Jacobus Arminius and Franciscus Gomarus, whose controversy over the nature of predestination thoroughly engaged with Augustine's anti-Pelagian thought, both had copies of Erasmus' Augustine in their private libraries, even though the new version was by now available in several reprints. ${ }^{62}$ Intriguing as these facts are, however, they do not prove that confessionalism was the decisive force behind the dissemination of these editions. For this was to an important extent also determined by practical economic factors. The cost of individual

6: Index de l'Inquisition Espagnole, I583, I584, ed. J.M. de Bujanda, et al. (Sherbrooke: Centre d'Etudes de la Renaissance, I993), 787-788.

60) Hieronymus Torrensis, Confessio Augustiniana (Dillingen: Sebald Mayer, 1567), sig. g4r. See also Hilmar M. Pabel, "Sixteenth-Century Catholic Criticism of Erasmus' Edition of St Jerome," Reformation and Renaissance Review 6 (2004): 23I-262.

61) The university library in Leiden possessed the 1556 Basel edition, Franeker the 1569 Basel edition. See Petrus Bertius, Nomenclator: The First Printed Catalogue of Leiden University Library (Facsimile, Leiden: University Library, 1995), sig. Ciro, and L.S. Wierda, Armamentarium totius sapientiae: Een arsenaal van alle wetenschap. De Franeker academiebibliotheek in de zeventiende eeuw (Leeuwarden: Fryske Akademy, 2005), 97.

62) See The Auction Catalogue of the Library of F. Gomarus: A Facsimile Edition with an Introduction and Indexes, eds. E. Dekker, J. Knoop, C.M.L. Verdegaal ('t Goy-Houten: HES, 1996), 3, nos. 64-65 (listing the edition of Basel, 1542); The Auction Catalogue of the Library of J. Arminius. With an introduction, ed. C.O. Bangs (Utrecht: HES, 1985), sig. A2 ${ }^{\mathrm{r}}$ (listing the edition of Paris, I54I). 
copies will have depended on the supply, which privileged Erasmus' more often reprinted edition. In some cases, however, there is clear evidence that patristic editions were associated with confessional politics. By i6os the Bodleian library in Oxford, for example, possessed four opera omnia editions of Augustine, two of Erasmus' version and two of that of the Leuven theologians. ${ }^{63}$ The generous patronage of Thomas Bodley made this financially possible, but it was Thomas James, his librarian, whose keen interest in patristics shaped the collection. A militant opponent of anything Catholic, James spent years collating patristic editions (to Bodley's increasing regret) in order to expose how the "Papists" had corrupted these texts with incompetent scholarship and censorship. ${ }^{64}$

Even when the reason for using a particular edition is unclear, however, it remains possible to explore the potential implications for individual users. Traces of reading are inherently fragmented, and it would go beyond the scope of this article to attempt a full survey. ${ }^{65}$ Yet two final examples of very different sixteenth-century users can provide some pointers on how the Erasmian Augustine could be read. First, Erasmus' guidance could be ignored. The Italian Reformer Peter Martyr Vermigli shows no sign of interest in Erasmus' critical apparatus. Whereas the ten volumes of his copy of the edition

63) See The First Printed Catalogue of the Bodleian Library I605. A Facsimile, ed. Thomas James, (Oxford: Clarendon Press, I986), I (Erasmus edition, Basel, I528-I529, misprinted as I52I), 4 (Lovanienses edition, Paris, 1586 and Erasmus edition, Basel, I569), 7 (Lovanienses edition, Antwerp, I577-I578).

64) See, in particular, A Treatise of the Corruptions of Scripture, Councils and Fathers by the Prelates, Pastors and Pillars of the Church of Rome for the Maintenance of Popery (London: H. L[ownes], I6I2; revised and corrected rpt. London: John W. Parker, I843), esp. xxx-xxxi on Erasmus, and 233-268 on censorship. See, in addition, Irena Backus, Historical Method and Confessional Identity in the Era of the Reformation (1378-16I5) (Leiden: Brill, 2003), 237-243. On Thomas James see the entry by R. Julian Roberts in the Oxford Dictionary of National Biography (Oxford: Oxford Universiy Press, 2004), 29:737-739 and N.R. Ker, "Thomas James's Collation of Gregory, Cyprian, and Ambrose," The Bodleian Library Record 4 (1952-1953): I6-29.

65) On the interpretation of readers' notes, see the seminal contribution of Anthony Grafton and Lisa Jardine, "Studied for action: How Gabriel Harvey read his Livy," Past and Present I29 (1990): 3-5I; and Grafton, "How Guillaume Budé Read His Homer," in Commerce with the Classics: Ancient Books and Renaissance Readers (Ann Arbor: University of Michigan Press, 1997), 135-183; more recently see Ann Blair, "Note-Taking as an Art of Transmission," Critical Enquiry 35 (2004): 8I-IO7 and "Scientific reading: an early modernist's perspective," Isis 95 (2004): 64-74; William H. Sherman, Used Books: Marking Readers in Renaissance England (Philadelphia: University of Pennsylvania Press, 2008), esp. 3-24. 
reveal systematic annotations, these concern only the text of Augustine. There are no notes on or underlinings of the preliminaries, censurae or marginal annotations. Vermigli did annotate the preface to his copy of Irenaeus but apparently found this unnecessary in the case of Augustine. ${ }^{66} \mathrm{He}$ clearly did not follow Erasmus' advice about certain spurious works: traces of reading are also present in works that Erasmus denounced, such as De praedestinatione dei and Hypognosticon, both in the seventh volume. Perhaps the accessibility of pseudepigraphic texts, printed among the authentic writings, constituted a stronger form of guidance than Erasmus' call to ignore (most of) these works in his censurae. In the version of the Leuven theologians, for example, these same texts were less readily available: all spurious works were relegated to appendices at the end of each volume, using a smaller type font which discouraged further reading.

Second, Erasmus' guidance could be misunderstood. The anonymous, contemporary user of a copy of the I 528 edition now preserved in Edinburgh, for example, diligently annotated his volumes. Yet his notes also reveal how he missed the point. For example, when Erasmus exposes the gloss presenting a silly etymology of the word "apostle," as mentioned above, this reader annotated and highlighted the argument of the gloss rather than Erasmus' scathing denunciation. ${ }^{67}$ Such examples illuminate the variety of responses by readers and indicate how even in those places where Erasmus was most visibly directing the interpretation of Augustine, his impact was always the result of a dynamic process.

66) Vermigli's Augustine is preserved in the Bibliothèque Publique et Universitaire in Geneva, sig. Bf 213. A copy of the Basel edition of 1543 was bought for Vermigli at the expense of Thomas Cranmer, who had invited Vermigli to come to England. For the cost account note, see William P. Haaugaard, "Renaissance Patristic Scholarship and Theology in Sixteenth-Century England," Sixteenth Century Journal Io (1979): 37-60, esp. 50 n 4I. Vermigli's library was later bought by the city of Geneva to form the basis of the library for Calvin's academy. See A. Ganoczy, La bibliothèque de l'académie de Calvin (Geneva: Droz, 1969). The Augustine edition is listed under no. 23, the edition of Irenaeus under no. 62 .

67) National Library of Scotland (deposited on long-term loan by East Lothian Council District), DPL I, vol. 2, p. I84. I have been unable to indentify the provenance of this copy more precisely. It contains numerous annotations in more than one hand. 


\section{Conclusion}

Although humanism is generally credited with introducing a more "scientific," methodical form of textual criticism, modern historians have long acknowledged that its program of a return to the sources was never a purely technical operation. Political realities necessarily shaped the editor's historical perspective, and even the most critical reading was informed by cultural norms and personal tastes. ${ }^{68}$ Despite Erasmus' claims to the contrary, his edition of Augustine provides a quite radical example of this phenomenon. He voices strong reservations about Augustine's style and reasoning while simultaneously praising his exemplary pastoral talents. An analysis of the paratextual presentation shows that his criticism is not just a result of a purely grammatical approach but part and parcel of his theological perspective. It also reveals how Erasmus' ambitions for theological reform not merely prompted his editions but also guided - and at times misguided-his critical eye.

Contemporary readers were aware of this perspective. In fact, the edition was soon controversial, especially within the Catholic world. Erasmus himself knew how such controversy could lead to aggressive polemics and even suppression. This pressure had caused him to neutralize the presentation of the works, in regard to both the organization and the critical apparatus. Yet the overall result still conveyed a strong theological message, much more so, in fact, than the official Catholic edition that followed in the second half of the sixteenth century. In this period confessional tensions increased, leading to Catholic censorship of Erasmus' scholarship, a clear example of intellectual discipline imposed from the top, in response to the humanist's calls for reform.

Erasmus' approach to Augustine has recently been characterized as promoting a "desacralized reading." Conservative, Catholic contemporaries of Erasmus would probably have agreed: Erasmus situates the work of a saint in a specific historical context, assesses his style as a grammarian, and is averse to theological disputations. Yet for Erasmus himself grammatical rigor and anti-scholastic comments did not diminish the holiness of Augustine. On the contrary, they were the means to revive the memory of the bishop of Hippo and as such provide an important ethical model in times of religious crisis. It is interesting to see how this perspective subsequently influenced the individual

68) See, for example, Anthony Grafton, Defenders of the Text: The Traditions of Scholarship in an Age of Science, I450-I800 (Cambridge, Mass.: Harvard University Press, 1991), I2-22; Michael D. Reeve, "Classical Scholarship," in The Cambridge Companion to Renaissance Humanism, ed. Jill Kraye (Cambridge: Cambridge University Press, 1996), 20-46. 
reader's perception of Augustine. Erasmus, for one, characteristically welcomed a critical attitude to his interpretation: "I do not want my judgment to impede anyone from profiting from his own." ${ }^{9}$ Further study of the readers of the Erasmian Augustine should reveal to what extent they listened to this advice.

69) Censura to De incarnatione verbi libri ii, vol. 4, p. 660: "Nec meum iudicium cuiquam obstare volo, quo minus fruatur suo." Similar statements occur in his censurae to Contra Fortunatum, vol. 6, p. II9, and De vita christiana, vol. 9, p. 607. 